\title{
The Age of Protocols: How the COVID-19 Pandemic Reshaped our Society
}

Dr. Murillo de Oliveira Dias ${ }^{1 *}$, Dr. Raphael de Oliveira Albergarias Lopes ${ }^{2}$

${ }^{1}$ Coordinator of Executive Education Programs at Fundação Getulio Vargas Brazil

${ }^{2}$ Fundação Getulio Vargas, Brazil

\section{Article History \\ Received: 07.08.2020 \\ Accepted: 22.09 .2020 \\ Published: 10.10 .2020}

Journal homepage:

https://www.easpublisher.com/easjpbs

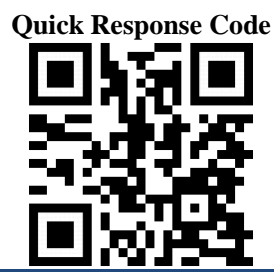

Copyright (C) 2020 The Author(s): This is an open-access article distributed under the terms of the Creative Commons Attribution 4.0 International License (CC BY-NC 4.0) which permits unrestricted use, distribution, and reproduction in any medium for non-commercial use provided the original author and source are credited.

\section{INTRODUCTION}

In April 2020, we questioned how the COVID19 pandemic would affect our society [1]. Six months after its publication, we observed a global adaptation to the coronavirus pandemic as part of daily life.

While this article is written, there is no cure for the coronavirus outbreak, declared by the WHO pandemic, on 11 March 2020. Therefore, the COVID19 is an infectious disease caused by severe acute respiratory syndrome coronavirus 2 , also known as SARS-CoV-2 [2].
By now, the COVID-19 symptoms are well documented, including (i) loss of smell; (ii) shortness of breath, (iii) sore throat and coughs, (iv) headaches, (v) abdominal or muscle pain [2].

Espite the best efforts and cooperation of most scientists, epidemiologists, and medical authorities, there is no cure while this study is written. However, at least 165 vaccines are being developed and tested to date [2].

The current treatment is prescribed with paracetamol and mechanical ventilation for eight days [2].The coronavirus - COVID-19 is illustrated in Figure 1 :

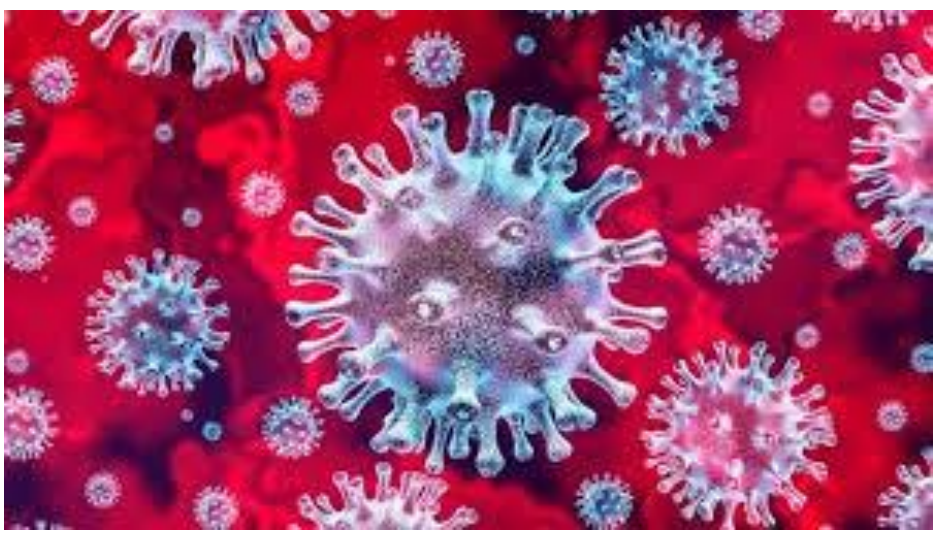

Fig-1: COVID-19. Source: WHO, 2020 


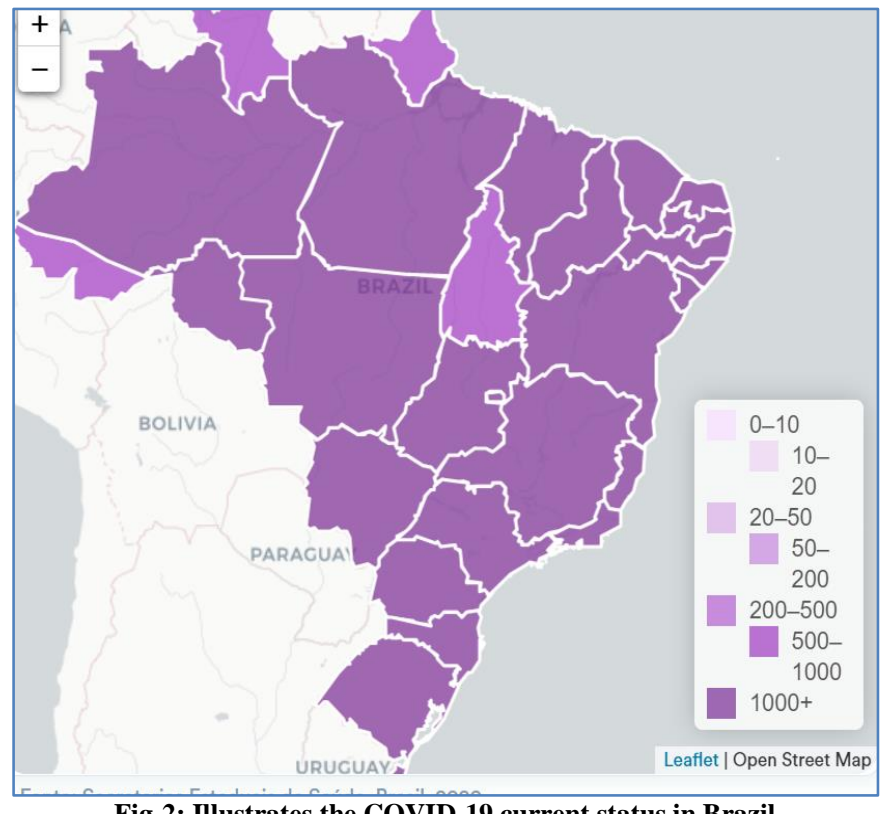

Fig-2: Illustrates the COVID-19 current status in Brazil

COVID-19 is essentially transmitted by saliva contact from coughs and sneezes. Much has been discussed about airborne transmission, with no conclusion.

The authors face six months of social isolation and loosening restrictions due to the curve-flattering in many countries, including Brazil.

However, much has already changed and incorporated in daily life. We address these changes in social behavior, social isolation impacts, and other consequences through a case study, in which the unit of analysis is coronavirus in Brazil [3].

According to the Brazilian Health authorities, there are currently 4,238,446 confirmed cases, from which 3,497,337 cases recovered and 129,522 deaths [4]. In the whole world, on 11 September 2020, there are 28,040,853 confirmed cases, with 906,092 deaths.

The objective is to promote an essential debate on the life adaptation strategies developed by the virus's communities. In the next section, we disclose the research and methods' limitations.

\section{RESEARCH METHODS}

The present qualitative research combined inductive reasoning and interpretive approach to encourage researchers to advance their studies. We adopted multiple methods approach, compiling a descriptive single case study, which unit of analysis is the COVID-19 spread over Brazil [3], with the extensive archival research, and direct participation and observation from the authors, directly affected by the changings in behaviors, to be discussed further.
The case under investigation is limited to Brazil. Other countries may vary in their social restriction policies and are not investigated in the present study.

\section{Covid-19: Brazil}

The coronavirus disease's first documented case was registered on 25 February 2020, with a 61year-old male, from São Paulo state, returning from Italy.

Figure 2 COVID-19 spread over Brazil, on 11 September 2020. Source: Brasil [5], Notice in Figure 2 that the less affected among the 27 states are Tocantins, Acre, Roraima, Amapá (light purple), center-west, and north regions.

\section{The age of protocols}

First, border control protocols. The Brazilian Federal Government has established the following protocols to citizens and visitors on August 2020, subject to be changed without previous warning, depending on the coronavirus results:

(i) The borders are open to citizens, residents, and tourists; differently from Portugal, for instance, Brazil does not require a negative-RT-PCR-COVID-19 test to enter Portugal.

(ii) Non-resident foreigners may enter for a period not exceeding 90 days and must present proof of purchase of health insurance, valid for use in Brazil with coverage for the entire trip (minimum coverage of approximately USD 5500).

In contrast, the US has adopted other border control protocols: in sum, non-residents that remained in the departure lounge) in the last 14 days by the Republic of China (except Hong Kong and Macau), Iran, the United Kingdom, Ireland, countries of the 
Schengen States and Brazil are not allowed to travel to the US to date. Figure 3 illustrates the differences in
COVID-19 spreads between Brazil and the United States:

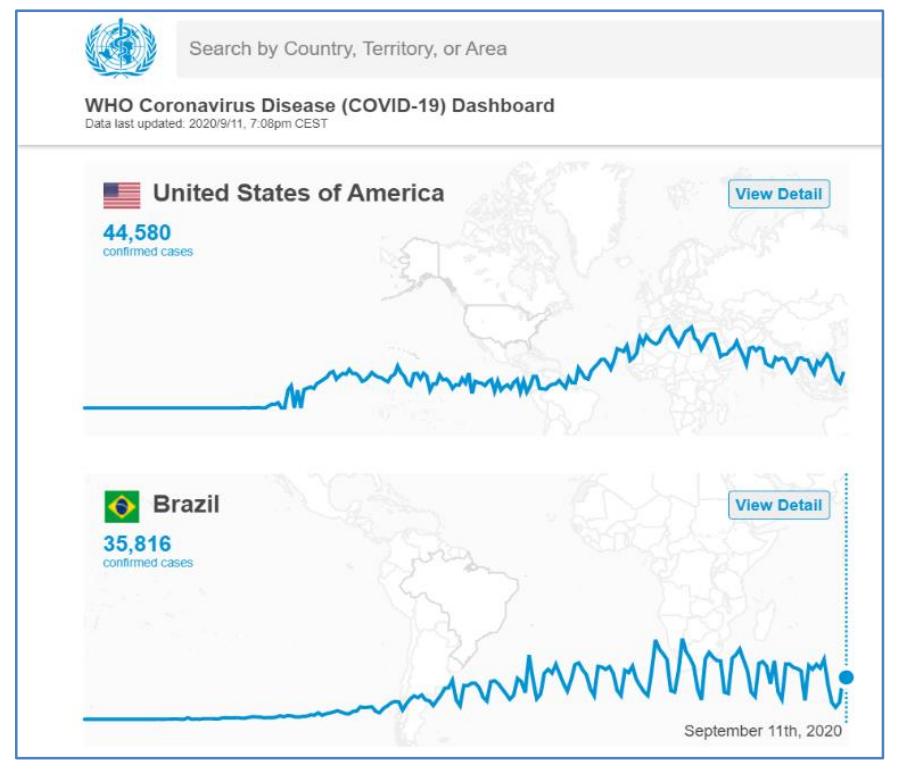

Fig-3: US x Brazil in the number of cases. Source: WHO, 2020

\section{HOW MANY PROTOCOLS?}

Brazil is the Federative Republic, a democratic regime, governed by one elected President, 27 state governors plus the Federal District (Brasilia) governor, and 5,570 mayors, everyone with their constitutional autonomy, as depicted in Figure 4:

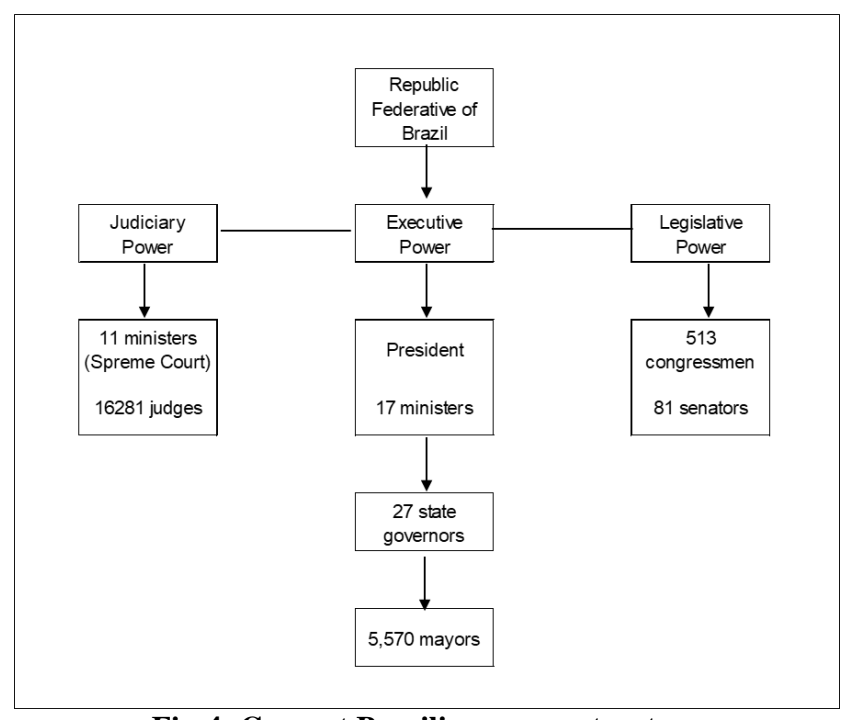

Fig-4: Current Brazilian power structure

Observe in Figure 4 that there are too many decision-makers in practice, and their efforts are not always balanced. For instance, in many cases during the pandemic, a given mayor decided instead of the state governor, regarding protocols for loosening social restrictions. Each state government has the autonomy to make decisions conflicting with other spheres of power, in many cases, suspended or prevented by judicial interference. For instance, in Rio de Janeiro state, the state government has determined the return of private schools to classes. On 11 August 2020, the judge Claudio Mello Tavares suspended the classes return in Rio de Janeiro Court of Justice [6].
For instance, in Rio de Janeiro State, restaurants, shopping centers, and gyms are opened with reduced operation capacity, seven days a week. In Aracaju, Sergipe - northeastern region, every shop is closed on Mondays due to the local mayor's monocratic decision.

Regardless state or municipality, however, some protocols are now part of the Brazilians' daily life, in which the majority of citizens have to adapt and, finally adopt, not limited to: 
(i) The use of masks is required in any public space within the country (not always respected);

(ii) The sanitization of all spaces was reinforced;

(iii) Alcohol gel $70 \%$ is offered everywhere, and hand cleaning is mandatory in all circumstances;

(iv) Elbow bumps or foot taps substituted handshakes;

(v) two-meter distance from each other in public spaces;

(vi) People are more understanding of each other and more empathetic than before the pandemic;

(vii) Increase of mental disorders, depression cases due to the coronavirus. According to the University of

Oxford study, for every sixteen patients infected with the COVID-19, one develops any mental disorder approximately three months after the contagion, such as anxiety, insomnia, and depression, to name a few [7].

(viii) Domestic violence, especially femicide rates in Brazil, increased 22 percent in 12 out of the 27 Brazilian states [5]

(ix) The consumer decision-making process and behavior have adapted to the coronavirus pandemic.

(x) The home office has become more than a trend;

(xi) Close relatives became closer; distant relatives, due to the mobility restrictions, have been in touch only through remote technology;

(xii) People tend to stay home more often than within the pandemic, even after the flexibilization of the restrictions;

(xiii) Shifts in sleep are reported;

(xiv) Parents have become full-time teachers, once classes are taught remotely;

(xv) More than one generation cohabits the same space simultaneously, with a strengthening of familial bonds, in most cases;

(xvi) The increase of crises of panic, uncertainty about the future amongst the population.

(xvii) Avoiding the television media, driven to the COVID-19 coverage, regularly playing their part in panic spreading amongst the population. Both authors have decreased dramatically their time dedicated to media coverage of COVID-19 in an attempt to preserve their mental health.

(xviii) Netflix and YouTube are considered the villains of the home office [8].

\section{DiscuSSION}

COVID-19 has dramatically reshaped our society in less than six months. The "new normal" includes unthinkable behaviors by the same time last year. The world had to face losses and social isolation and develop new ways to deal with grief, pain, and be more empathetic and supportive.

Many voluntary initiatives, robust at the beginning of the pandemic, are less evident than three months ago. Supermarket and Pharmacy shortages have ended, the supply has been normalized, but the general prices of goods have increased. Classes have been dispensed remotely by communication technology, such as Zoom, Google Teams, or equivalent.

The following industries were severely impacted by the COVID-19 pandemic, not restricted to: (i) carmaker industry [9, 10]; (ii) aircraft manufacturer industry [11-13]; (iii) government and non-government activities [13; Paradela, Dias MO, Assis O, Fonseca J, R. [14]; (iv) brewing industry [15].

Since the shopping centers reopening, many companies kept their doors closed indefinitely. Finally, people endured and survived, to this natural selection process, the survival of the fittest. These adjustments gave birth to countless protocols, part of the daily life of billions of people.

\section{Future RESEARCH}

Shortly, we will revisit this case to describe the evolution of the COVID-19 pandemic regarding Brazil. This article followed Dias \& Lopes [16], preliminary study on the subject. Future research is encouraged virtually in all business administration domains, mainly investigating the impacts of the COVID-19 over countless business segments.

\section{REFERENCES}

1. Dias, M., Lopes, R. (2020). Will the COVID-19 Pandemic Reshape our Society? EAS Journal of Humanities and Cultural Studies, 2(2), 93-97

2. WHO. (2020). Rolling updates on coronavirus disease (COVID-19) Retrieved from https://www.who.int/emergencies/diseases/novelcoronavirus-2019/events-as-they-happen, on 30 March 2020.

3. Yin, R. (1988). Case Study Research: Design and Methods. Newbury Park, CA: Sage Publications.

4. Coronavirus, B. (2020). Painel Coronavirus. Retrieved on 11 September 2020 from https://covid.saude.gov.br/

5. Agencia, B. (2020). Casos de feminicídio crescem $22 \%$ em 12 estados durante pandemia Retrieved on 12 September 2020, from https://agenciabrasil.ebc.com.br/direitoshumanos/noticia/2020-06/casos-de-feminicidiocrescem-22-em-12-estados-durante-pandemia

6. Diário do Rio. (2020). Justiça mantém suspensa volta às aulas de escolas particulares do Rio. Retrieved on 12 September 2020, from https://diariodorio.com/justica-mantem-suspensavolta-as-aulas-de-escolas-particulares-do-rio/

7. UOL. (2020). Vítimas de covid-19 têm mais insônia, ansiedade e depressão, diz estudo. Retrieved on 12 September 2020, from https://www.uol.com.br/vivabem/noticias/redacao/ 2020/08/19/transtorno-mental-covid-19-tres-mesesestudo.htm 
8. Dias, M. (2020b). Netflix: from Apollo 13 to the Coronavirus Pandemic. Global Scientific Journals, 8(8), 21-35.

9. Dias, M., Navarro, R., Valle, A. (2013). BMW and Brazilian Federal Government: Enhancing the Automotive Industry Regulatory Environment. International Journal of Arts and Sciences, 6(2), 551-567. doi: 10.6084/m9.figshare.7834742

10. Dias, M. (2014). FIAT and Chrysler in Brazil: Anatomy of an Alliance. International Journal of Business and Management Studies, 3(1), 1-13.

11. Cruz, B.S., Dias, M. (2020). Crashed Boeing 737MAX: Fatalities or Malpractice? Global Scientific Journals, 8(1), 2615-2624.

12. Dias, M., Duzert, Y. (2016). Fiat Chrysler Automobiles in Brazil: Alliance Consolidated. The
International Journal of Business \& Management, 4(2), 160-166.

13. Dias, M. (2018). Heineken Brewing Industry in Brazil. International Journal of Management, Technology and Engineering, 8(9), 1304-1310.

14. Dias, M. (2019a). Air transportation in Brazil: Guarulhos International Airport. In: South Asian Research Journal of Business and Management, 1(4), December/2019, pp. 182-187.

15. Dias, M., Falconi, Davi. (2018). The Evolution of Craft Beer Industry in Brazil. Journal of Economics and Business, 1(4), 618-626.

16. Dias, M., Lopes, R. (2020). Case on fatal Ship Failure Services: Onboard. Arabian Journal of Business and Management Review (Kuwait Chapter), 9(1), 10-19. 